\title{
Structural and productive characteristics of Marandu and Xaraés grasses fertilized at different times after harvesting ${ }^{1}$
}

\section{Rosana Cristina Pereira ${ }^{2}$, Karina Guimarães Ribeiro ${ }^{3}$, Rodrigo Duarte de Andrade ${ }^{2}$, Janaina de Lima Silva ${ }^{4}$, Enilson de Barros Silva ${ }^{5}$, Dilermando Miranda da Fonseca ${ }^{6}$, Paulo Roberto Cecon 7 , Odilon Gomes Pereira ${ }^{6}$}

\author{
1 Project funded by FAPEMIG. \\ 2 Programa de Pós-Graduação em Produção Vegetal, UFVJM. \\ 3 Departamento de Zootecnia, UFVJM. \\ 4 Programa de Pós-Graduação em Zootecnia, UFVJM. \\ ${ }^{5}$ Departamento de Agronomia, UFVJM. \\ ${ }^{6}$ Departamento de Zootecnia, UFV. \\ ${ }^{7}$ Departamento de Informática, UFV.
}

ABSTRACT - The objective of this study was to assess the effect of applying $\mathrm{N}$ and $\mathrm{K}_{2} \mathrm{O}$ at different times after harvest on the structure and production characteristics of Marandu and Xaraés cultivars of Brachiaria brizantha. Two greenhouse $4 \times 2$ factorial experiments using a randomized block design with eight treatments and four replicates were carried out. In experiment 1 , the plants in pots were fertilized weekly with $50 \mathrm{mg} / \mathrm{dm}^{3}$ of $\mathrm{N}$ and $\mathrm{K}_{2} \mathrm{O}$ until a week before a uniformity cut, for a total of four applications. After cutting, plants were fertilized with $50 \mathrm{mg} / \mathrm{dm}^{3}$ of $\mathrm{N}$ and $\mathrm{K}_{2} \mathrm{O}$ at $0,3,6$, and 9 days. Cultivars were evaluated after 44 days of regrowth. In experiment 2, a single $50 \mathrm{mg} / \mathrm{dm}^{3}$ dose of $\mathrm{N}$ and $\mathrm{K}_{2} \mathrm{O}$ was applied a week before the uniformity cut, and $100 \mathrm{mg} / \mathrm{dm}^{3}$ of $\mathrm{N}$ and $\mathrm{K}_{2} \mathrm{O}$ were applied at $0,4,8$, and 12 days after cutting; cultivars were evaluated after 39 days of regrowth. In experiment 1, the leaf/stem ratio and dry matter yield were influenced by the time at which fertilizers were applied. In the second experiment, the total number of leaves, expanded leaves, dead leaves, and the leaf lamina accumulated length and dry matter production were influenced by the time at which fertilizers were applied. Marandugrass had more leaves and tillers than cv. Xaraés, which, in turn, had greater height, dry matter yield and regrowth vigor. Applying nitrogen and potassium fertilizer immediately after cutting improves the structural characteristics, while the dry matter yield is maximized by applying fertilizers immediately after cutting by using lower doses of $\mathrm{N}$, or at 4.5 days after cutting by using higher doses of $\mathrm{N}$.

Key Words: crude protein, dry matter, leaf/stem ratio, nitrogen uptake, number of leaves, number of tillers

\section{Introduction}

Successful use of pastures depends on nutrient availability, choice of forage, understanding of morphophysiological mechanisms and their interactions with the environment, and management, which are essential for forage growth and persistence (Fagundes et al., 2006).

Continuous growth of leaves and tillers is a sign of forage yield; these processes are crucial for restoring leaf area after grazing or cutting and producing forage perennially (Gomide \& Gomide, 2000). Tillering is a structural feature that is strongly affected by nutritional, environmental, and management factors (Garcez Neto et al., 2002). Fertilization, cutting height and grazing are some of the factors that affect tillering.

Nitrogen $(\mathrm{N})$ fertilization may affect structural characteristics and forage yield. The nutrient that plants most absorb from the soil is $\mathrm{N}$; it affects the number of tillers, leaves, and the leaf area, and is, therefore, an important plant yield factor (Megda \& Monteiro, 2010). Low N levels keep the emergence rate of new tillers below their potential rate in tropical forage grasses. Applying $\mathrm{N}$ has a positive effect on the dry matter yield, the number of leaves, leaf area, the final leaf length (Martuscello et al., 2005), and the number of tillers in B. brizantha (Rodrigues et al., 2006).

Nitrogen fertilization also has a positive effect on the number of dead or senescent leaves (Silva et al., 2009), because there are more leaves and therefore more shading. Thus, adequate $\mathrm{N}$ dosages at appropriate times are required to avoid forage loss due to high senescence rates.

Studies of structural characteristics and the yield of different forage cultivars are important for defining the most adequate management of pastures. Megda \& Monteiro (2010) suggested that the dry matter yield of the aerial portion of B. brizantha cv. Marandu correlates positively with the number of tillers, leaves, and the leaf area. 
The purpose of this study was to assess the effect of applying $\mathrm{N}$ and $\mathrm{K}_{2} \mathrm{O}$ at different times after cutting on the structure and production characteristics of Marandu and Xaraés cultivars.

\section{Material and Methods}

Two greenhouse experiments were carried out at the Forage Cultivation Sector (Setor de Forragicultura) of the Animal Science Department, J. K. campus, Universidade Federal dos Vales do Jequitinhonha e Mucuri (or UFVJM), in Diamantina, which is located in the Alto Vale do Jequitinhonha region, Minas Gerais state. Experiment 1 was from March to May 2008, and experiment 2, from November 2008 to January 2009. The J. K. campus is located at $1,400 \mathrm{~m}$ altitude, $18^{\circ} 9^{\prime}$ S latitude and $43^{\circ} 21^{\prime}$ 'WGR. The climate type is Cwb (warm temperate with dry winters) according to the Köppen classification.

The maximum and minimum temperatures were recorded daily using a hood thermometer in each greenhouse. The mean maximum and minimum temperatures were $32.5^{\circ} \mathrm{C}$ and $11.9^{\circ} \mathrm{C}$ (experiment 1 ), and $32.5^{\circ} \mathrm{C}$ and $15.8^{\circ} \mathrm{C}$ (experiment 2).

A typical Orthic Quartzarenic Neosoil was used (Embrapa, 2006); it was obtained from the Forage Cultivation Sector from a 0- to 20-cm layer, then it was dried, sieved (4.0-mm mesh), and sampled for chemical analysis.

The soil characteristics were: $\mathrm{pH}\left(\mathrm{H}_{2} \mathrm{O}\right)=5.8$; $\mathrm{P}$ and $\mathrm{K}$, 0.9 and $14 \mathrm{mg} / \mathrm{dm}^{3}$; Ca, Mg, Al, H+Al, SB, effective CEC and CEC at pH 7.0 were $0.9 ; 0.4 ; 0.2 ; 2.4 ; 1.3 ; 1.5 ; 3.7 \mathrm{cmol}_{\mathrm{c}} / \mathrm{dm}^{3}$; the aluminum saturation was $13 \%$ and the base saturation was $36 \%$; organic matter was $0.8 \mathrm{dag} / \mathrm{kg}$.

Liming was not required, based on a soil analysis (Ribeiro et al., 1999). A first fertilization consisted of applying $300 \mathrm{mg} / \mathrm{dm}^{3}$ phosphorus (experiments 1 and 2).

The experiment design was a $4 \times 2$ factorial arrangement in a randomized block design with eight treatments and four replicates. A study was made out of four nitrogen $(\mathrm{N})$ and potassium $\left(\mathrm{K}_{2} \mathrm{O}\right)$ fertilizer applications after cutting of two Brachiaria brizantha cultivars (Marandu and Xaraés). Fertilizers were applied at $0,3,6$, and 9 days after cutting for uniformity in experiment 1 , and at $0,4,8$, and 12 days after a similar cut in experiment 2 . The experiment units were plastic pots containing $5.0 \mathrm{dm}^{3}$ of soil.

Forages were sowed on trays with washed sand; about two weeks later, ten seedlings were transplanted per pot. Thinning was done ten days after transplantation to leave five plants per pot; the idea was to attain plant uniformity.
Experiment 1 consisted of thinning the plants and applying $50 \mathrm{mg} / \mathrm{dm}^{3} \mathrm{~N}$ and $\mathrm{K}_{2} \mathrm{O}$ every seven days up to a week before uniformity cutting; this totaled four fertilizer applications of $400 \mathrm{~kg} / \mathrm{ha} \mathrm{N}$ and $\mathrm{K}_{2} \mathrm{O}$. Two plants were tagged with colored ribbons in each pot. The main tiller and existing tillers before uniformity cutting were identified in each pot; the mean was five tillers.

Five weeks after transplantation, uniformity cutting was done $5 \mathrm{~cm}$ from the soil surface with pruning shears. To assess the treatments, single $50 \mathrm{mg} / \mathrm{dm}^{3} \mathrm{~N}$ (ammonium sulfate) and $\mathrm{K}_{2} \mathrm{O}$ (potassium chloride) doses $-100 \mathrm{~kg} / \mathrm{ha}$ - were applied 0, 3, 6, and 9 days after uniformity cutting.

Experiment 2 consisted of pruning the plants and applying single $50 \mathrm{mg} / \mathrm{dm}^{3} \mathrm{~N}$ and $\mathrm{K}_{2} \mathrm{O}$ (100 kg/ha) doses, which corresponded to fertilization with $100 \mathrm{~kg} / \mathrm{ha}$ of $\mathrm{N}$ and $\mathrm{K}_{2} \mathrm{O}$. Three plants per pot were tagged with colored ribbons; the main tiller and existing tillers before uniformity cutting were identified. The mean was three tillers.

Two weeks after transplantation, uniformity cutting was done $5 \mathrm{~cm}$ from the soil surface. To assess the treatments, single $100 \mathrm{mg} / \mathrm{dm}^{3} \mathrm{~N}$ and $\mathrm{K}_{2} \mathrm{O}(200 \mathrm{~kg} / \mathrm{ha})$ doses were applied $0,4,8$, and 12 days after cutting.

In both experiments, the soil in pots was watered daily and kept close to field capacity.

The structural characteristics that were evaluated in both experiments were: total number of leaves, which was the sum of emergent, fully expanded, senescent, and dead leaves; number of fully expanded leaves, which was the sum of live leaves with an exposed ligule; and the number of tillers per plant, which was the sum of tillers arising in each plant after uniformity cutting. The leaf area was also evaluated in experiment 1; it was measured through a leaf area meter (CI-202 Portable Leaf Area Meter). The accumulated blade length, measured in centimeters from the leaf apex to the ligule by using a ruler, and the total number of dead leaves, measured by adding senescent and dead leaves were assessed experiment 2 .

All plants were harvested at soil level after 44 (experiment 1 ) and 39 days of growth (experiment 2). Plants were weighed to assess the dry matter yield, and separated into leaf blade and stem + sheath to find the leaf blade/stem ratio. Leaf blade and stem + sheath samples were pre-dried in a forced-ventilation oven at $60{ }^{\circ} \mathrm{C}$ for 72 hours, then weighed separately and treated by mixing and grinding in a Willey-type mill, and stored in closed recipients. Subsequent analyses consisted of measuring the dry matter and crude nitrogen/protein content, as described by Silva and Queiroz (2002), and then calculating $\mathrm{N}$ absorption per pot based on the resulting dry matter and the $\mathrm{N}$ content of plants in pots per treatment. 
The leaf blade/stem ratio was calculated as the ratio between the leaf blade and stem dry masses; the leaf blade and stem ratio was used for calculating the weighted mean dry matter content of an air-dried sample taken from the whole plant; it was then multiplied by the dry matter content of an oven-dried sample to obtain the dry matter content.

Twenty-one days after harvesting, plants were cut at soil level to measure regrowth vigor in both experiments. The material was placed in a forced ventilation oven at $55^{\circ} \mathrm{C}$ for 72 hours to measure the dry weight (Cecato et al., 2000); a final drying was performed to find the dry matter yield.

Analysis of variance was applied to the data. The means of the Marandu and Xaraés cultivars were tested using the F test (5\%). Polynomial regression was applied to the $\mathrm{N}$ and $\mathrm{K}_{2} \mathrm{O}$ application times. The criteria for selecting the polynomial regression models were significance and higher regression coefficient values. The determination coefficient was calculated as follows: $\mathrm{r}^{2} / \mathrm{R}^{2}=$ sum of the square of the regression/sum of the treatment square. The SAEG software (Sistema de Análises Estatísticas e Genéticas - SAEG, versão 8.0) was used.

\section{Results and Discussion}

Experiment 1 revealed a difference in the total number of leaves per plant and per tiller $(\mathrm{P}<0.05)$ between Brachiaria brizantha cultivars: Marandu (62.3 leaves/plant and 4.0 leaves/tiller) had higher values compared with Xaraés (40.2 leaves/plant and 3.3 leaves/tiller) (Table 1). Leaf number is used in experiments assessing forage cultivars because of their genetic influence (Gomide \& Gomide, 2000); the total number of leaves per tiller is an important plant variable, as it had a direct effect on the dry matter yield. Alexandrino et al. (2004) assessed the effect of $\mathrm{N}$ fertilization ( 0 to $40 \mathrm{mg} / \mathrm{dm}^{3} \mathrm{~N}$ per week) and the regrowth time ( 0 to 48 days after uniformity cutting) on the morphogenetic and structural characteristics of Brachiaria brizantha Marandu cv. and found more leaves/tiller (5.03) after fertilization with $20 \mathrm{mg} / \mathrm{dm}^{3} /$ week at 39 days of regrowth. Silva et al. (2009) assessed the morphogenetic and structural characteristics of $B$. brizantha cv. Marandu when fertilized with four doses of $\mathrm{N}$ (0 to $225 \mathrm{mg} / \mathrm{dm}^{3}$ ), and reported an average of 7.5 leaves/tiller. Variations of the total number of leaves per tiller in the Marandu cv. may be due to differences in environmental variables, such as temperature, water availability and sunlight intensity, as well as in management, such as fertilization level and time and age or the plant development stage at harvest. The nutrient that plants most extract from the soil is $\mathrm{N}$; it affects the number of tiller and leaves and the leaf area (Megda \& Monteiro, 2010). These authors also emphasized the influence of interactions between nutrients - such as between $\mathrm{N}$ and $\mathrm{K}$ - on these variables.

The times of application of fertilizer and the interaction between cultivar and these times had no effect $(\mathrm{P}>0.05)$ on the total number of leaves per plant and per tiller. Four $50-\mathrm{mg} / \mathrm{dm}^{3} \mathrm{~N}$ doses were applied at seven-day intervals before cutting for uniformity - this corresponded to a total $400-\mathrm{kg} / \mathrm{ha} \mathrm{N}$ that was applied. This amount of nitrogen may have helped reduce the effect of the fertilizer application times, as fertilizers were applied up to one week before harvesting. Premazzi et al. (1999) assessed different doses of $\mathrm{N}$ applied 0 and 7 days after cutting Tifton- 85 grass, and found no effect due to the fertilizer application time on the number of leaves per plant and per tiller. Nabinger \& Pontes (2001) reported major variations in the number of leaves between and within species as a function of management and climate.

Cultivars differed $(\mathrm{P}<0.05)$ in the number of expanded leaves per plant per plant and per tiller (Table 1). The Marandu cv. (40.8 and 2.6) had higher values compared with the Xaraés cv. (23.5 and 1.9); it also had a higher percentage of expanded leaves relative to the total number of leaves compared with the Xaraés cv. $(65 \% \times 58 \%)$. This is an important feature, because fully expanded leaves contribute most to fixating $C$ in photosynthesis (Pedreira et al., 2001). There were no effects of fertilizer application times or cultivar/application time interaction with the number of expanded leaves per plant.

The number of tillers per plant was altered $(\mathrm{P}<0.05)$ in each cultivar (Table 1); the Marandu cv. (15.6) had a higher number of tillers than the Xaraés cv. (12.1). The Marandu cv. had more leaves and tillers, a coherent finding as each leaf had one or more axillary buds that can generate more

Table 1 - Total number of leaves per plant (TNL/pl), total number of leaves per tiller (TNL/tiller), number of expanded leaves per plant (NEL/pl), number of expanded leaves per tiller (NEL/tiller), number of tillers (NT), leaf blade/stem ratio (L/S), dry matter yield per pot (DMY/pot, in g/pot), and regrowth vigor (RV, in g/pot) of Marandu and Xaraés cultivars

\begin{tabular}{|c|c|c|c|c|c|c|c|c|}
\hline Cultivar & $\mathrm{TNL} / \mathrm{pl}$ & TNL/tiller & $\mathrm{NEL} / \mathrm{pl}$ & NEL/tiller & $\mathrm{NT} / \mathrm{pl}$ & $\mathrm{L} / \mathrm{S}$ & $\mathrm{DMY} / \mathrm{pot}$ & RV \\
\hline Marandu & $62.3 a$ & $4.0 \mathrm{a}$ & $40.8 a$ & $2.6 a$ & $15.6 a$ & $0.48 \mathrm{a}$ & $32.14 \mathrm{a}$ & $2.51 b$ \\
\hline Xaraés & $40.2 b$ & $3.3 b$ & $23.5 b$ & $1.9 \mathrm{~b}$ & $12.1 \mathrm{~b}$ & $0.42 b$ & $34.85 a$ & $3.44 \mathrm{a}$ \\
\hline
\end{tabular}

Means followed by different letters differ by $\mathrm{F}$ test. 
tillers (Nabinger \& Pontes, 2001). The fertilizer application time or the interaction between the cultivar and fertilizer application time had no effect on the number of tillers in this study. Megda \& Monteiro (2010), Silva et al. (2009) and Alexandrino et al. (2004), however, found a positive effect of $\mathrm{N}$ fertilization on tillering in $\mathrm{B}$. brizantha. Medeiros et al. (2011) found an increased tiller density as a function of N levels and cutting time in Marandu and Vitoria cultivars; there was a $20.7 \%$ increase in tillers per pot when the cutting time was 65 days (26.83 tillers/pot) rather than 45 days (22.23 tillers/pot). Converting to number of tillers/plant, the values were 4.45 at 45 days and 5.37 at 65 days.

The leaf area was not affected $(\mathrm{P}>0.05)$ by the cultivar, fertilizer application time, or interaction between the cultivar and the fertilizer application time point; the means were $297.49 \mathrm{~cm}^{2}$ per plant and $21.58 \mathrm{~cm}^{2}$ per tiller. The leaf area is a genetic feature for distinguishing cultivars; although the Marandu cv. had higher total number of leaves and number of tillers, its leaf area was lower than that of the Xaraés cv. This finding suggests a possible compensation between the number of leaves and size, where the Xaraés cv. had fewer but larger leaves and tillers. Martuscello et al. (2005) found a positive linear effect by $\mathrm{N}$ on the leaf length and area, an evidence of a cell division promoting effect due to $\mathrm{N}$, which produces new cells and increases the leaf rate and length, thereby changing the final leaf size.

The cultivar and times of application of fertilizer affected $(\mathrm{P}<0.05)$ the leaf blade/stem ratio (Table 1 ); the Marandu cv. had a higher leaf blade/stem ratio ratio (0.48) compared with the Xaraés cv. (0.42). These numbers were used to calculate the blade proportions (32.43 and $29.58 \%$, respectively). Leaf blade is a major component of the plant dry matter yield; it is one of the sunlight capturing structures and a substantial portion of active photosynthetic tissue. This results in the production of plant photoassimilates, and provides high nutritional value forage for ruminants (Alexandrino et al., 2004). High $\mathrm{N}$ doses may have contributed to increased plant growth and early stem lengthening.

There was an effect of the of fertilizer application $(\mathrm{P}<0.05)$; however, no equation that explained the data on the leaf blade/stem ratio was found. The mean values were $0.51,0.46,0.47$, and 0.46 for the Marandu cv., and 0.42, 0.40, 0.43 , and 0.40 for the Xaraés cv., which were fertilized at 0 , 3,6 , and 9 days after cutting.

The cultivars did not differ $(\mathrm{P}>0.05)$ in the dry matter yield per pot (Table 1); the dry matter yield of the Xaraés cultivar was $34.85 \mathrm{~g} /$ pot; it was $32.14 \mathrm{~g} /$ pot for the Marandu cultivar. Silva et al. (2009) have shown that plants with a higher number of tillers have a higher yield and better soil cover. However, the Marandu cv. had a higher number of tillers and a similar dry matter yield, which suggested that its tillers were lighter than those of the Xaraés cv.

Interactions between the application time and the cultivar had no effect on the dry matter yield per pot; it was, however, affected by the fertilization time point (Figure 1). A delay of up to 4.8 days in the application of fertilizer after cutting reduced the dry matter yield/pot; fertilization at this time resulted in $30.97 \mathrm{~g} /$ pot. Thus, application soon after cutting appears to be the recommended value for the fertilizer doses evaluated in this study. On the other hand, a higher dry matter yield/pot 9 days after cutting was not consistent. Premazzi et al. (2002) found no effect of $\mathrm{N}$ application time ( 0 and 7 days after cutting) on the dry matter yield in the aerial portion of the Tifton-85 grass.

Contents of dry matter (DM), nitrogen (N), crude protein (CP), and absorption of $\mathrm{N}$ were not affected by the cultivar, application time or interaction between fertilizer application time and the cultivar. The respective mean values of $\mathrm{N}$ were $23.5 \%, 1.5 \%$, $9.38 \%$, and $0.83 \mathrm{~g} /$ pot. Nitrogen fertilization affects the $\mathrm{N}$ content and consequently the $\mathrm{CP}$ content (Medeiros et al., 2011; Maranhão et al., 2009). Monteiro et al. (1995) recorded an $\mathrm{N}$ content of $2.68 \%$ in plants corresponding to a $16.8 \%$ CP content - in Brachiaria brizantha Marandu cv. cultivated in a soil with all macronutrients. There was only $0.85 \%$ of $\mathrm{N}$ in plants $(5.31 \%$ $\mathrm{CP})$ in soils lacking nitrogen.

There were differences $(\mathrm{P}<0.01)$ in $B$. brizantha cultivars in regrowth vigor assessed 21 days after cutting (Table 1 ). The Xaraés cv. had a higher regrowth vigor (3.44 g/pot) compared with the Marandu cv. (2.51 g/pot), which concurs with Valle et. al (2001), who found that the Xaraés cv. has quicker regrowth than the Marandu cv. The $\mathrm{N}$ application time and the interaction between application time and cultirvar had no effect on regrowth vigor.

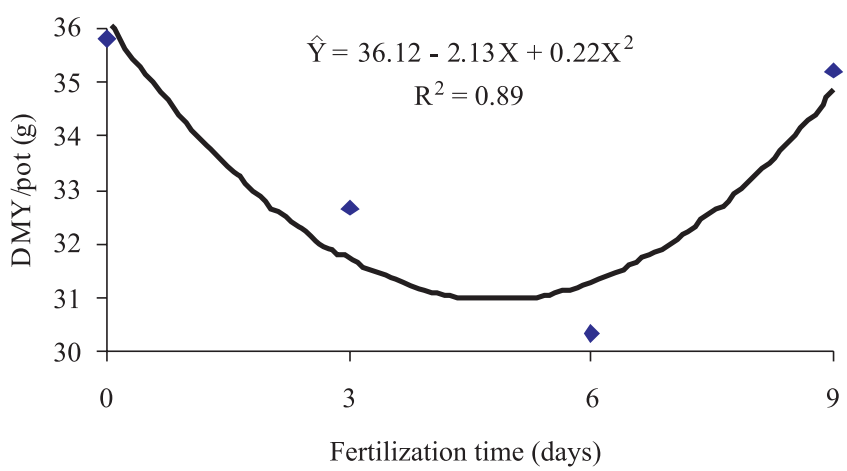

Figure 1 - Dry matter yield per pot (DMY/pot) as a function of fertilization time after cutting (mean values of Marandu and Xaraés cultivars). 
In experiment 2, a cultivar effect for total number of leaves per plant and per tiller (Table 2) was observed; the Marandu cv. (28.9 leaves/plant and 3.5 leaves/tiller) had higher values compared with the Xaraés cv. (24.6 leaves/ plant and 3.2 leaves/tiller). The total number of leaves per plant recorded is lower for both cultivars compared with values of total number of leaves in experiment 1 . Fulkerson and Slack (1995), cited by Alexandrino et al. (2004), stated that each species defines its number of live leaves per tiller, and that differences may be due to environmental variables (mostly temperature and light intensity) and management (applied $\mathrm{N}$ and $\mathrm{K}_{2} \mathrm{O}$ levels and time of uniformity cutting after transplantation). In experiment 1 , plants had a larger supply of $\mathrm{N}$ and $\mathrm{K}_{2} \mathrm{O}$, and uniformity cutting was done 35 days after transplantation (it was done at 15 days in experiment 2 ) when the demand for plant resources to establish a root system and the aerial portion until the first harvest were still high.

The total number of leaves per tiller (Figure 2) varied as a function of fertilizer application times; the recommendation was to apply fertilizer on the cutting day to attain higher total number of leaves per tiller, as there was an estimated 0.048-leaves/tiller decrease for each day in which fertilization was delayed relative to the day in which cutting was done.

The effect of the cultivar on the number of expanded leaves per plant per plant and per tiller (Table 2) was that the cultivar Marandu (19.6 and 2.36) was superior to Xaraés (15.5 and 2.01).

There was effect of fertilizer application time on the number of expanded leaves per plant per tiller, which consisted of a negative linear response of cultivars as the fertilizer application intervals increased (Figure 3). The estimated number of expanded leaves per plant per tiller reduction was 0.028 for each delay in nutrient availability.

There was no cultivar, time of fertilizer application, or cultivar/application time interaction effects for the number of dead leaves per plant; the mean value was 4.7 dead leaves, which is $17.6 \%$ of the mean total number of leaves of cultivars.

There was no cultivar effect on the number of dead leaves per tiller; the mean value was 1.6 dead leaves/tiller. There was a fertilizer application time effect (Figure 4) in which the maximum number of dead leaves was 1.83 after

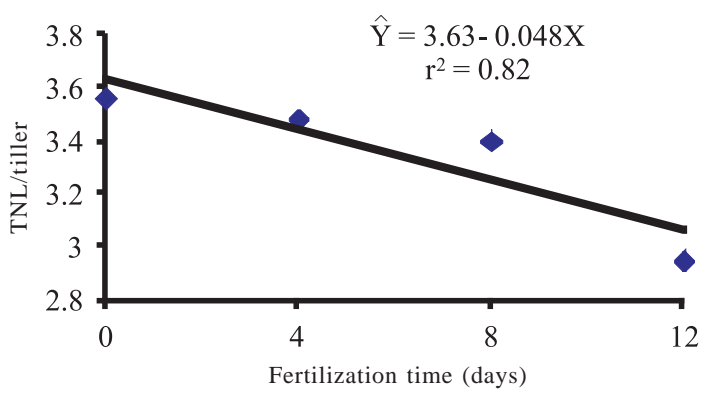

Figure 2 - Total number of leaves (TNL) per tiller as a function of the fertilization time (moment) after cutting (mean values for Marandu and Xaraés cultivars).

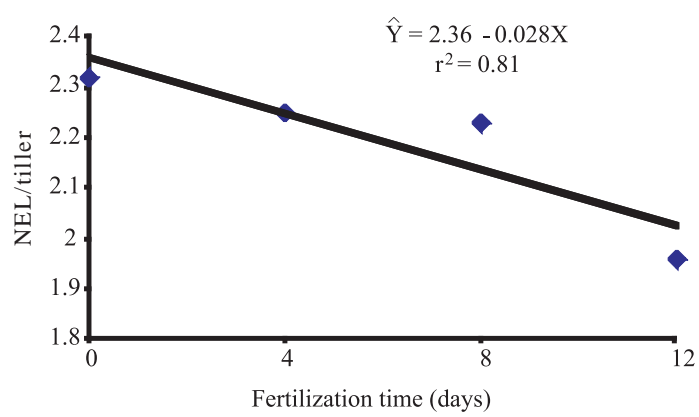

Figure 3 - Number of expanded leaves (NEL) per tiller as a function of fertilization time after cutting (mean values of Marandu and Xaraés cultivars).

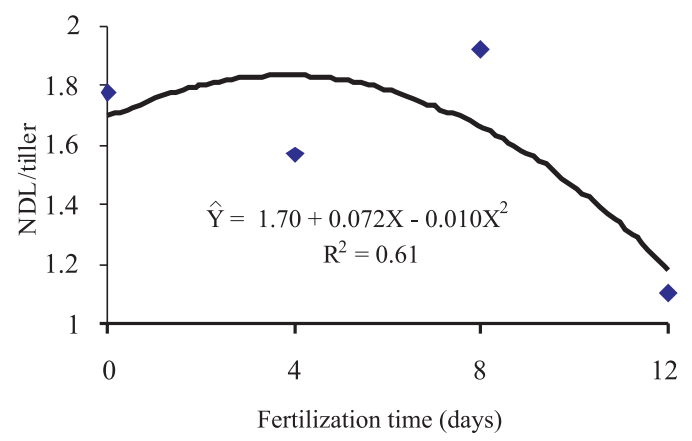

Figure 4 - Number of dead leaves (NDL) per tiller as a function of fertilization time after cutting (mean values of Marandu and Xaraés cultivars).

Table 2 - Total number of leaves per plant (TNL/pl), total number of leaves per tiller (TNL/tiller), number of expanded leaves per plant $(\mathrm{NEL} / \mathrm{pl})$, number of expanded leaves per tiller (NEL/tiller), number of tillers (NT), height (in cm), leaf blade/stem (L/S) ratio, dry matter yield per pot (DMY/pot, in g/pot), and regrowth vigor (RV, in g/pot) of Marandu and Xaraés cultivars

\begin{tabular}{|c|c|c|c|c|c|c|c|c|c|}
\hline Cultivar & $\mathrm{TNL} / \mathrm{pl}$ & TNL/tiller & $\mathrm{NEL} / \mathrm{pl}$ & NEL/tiller & $\mathrm{NT} / \mathrm{pl}$ & Height & $\mathrm{DMY} / \mathrm{pot}$ & $\mathrm{L} / \mathrm{S}$ & $\mathrm{RV}$ \\
\hline Marandu & $28.9 a$ & $3.5 a$ & $19.6 a$ & $2.4 \mathrm{a}$ & $8.3 a$ & $21.6 b$ & $25.3 b$ & $2.1 \mathrm{~b}$ & $3.56 b$ \\
\hline Xaraés & $24.6 \mathrm{~b}$ & $3.2 \mathrm{~b}$ & $15.5 b$ & $2.0 \mathrm{~b}$ & $7.7 \mathrm{~b}$ & $28.4 b$ & $27.8 \mathrm{a}$ & $2.4 \mathrm{a}$ & $5.22 \mathrm{a}$ \\
\hline
\end{tabular}

Means followed by different letters differ by $\mathrm{F}$ test. 
applying fertilizers 3.6 days after cutting. This behavior was similar to that pertaining to the dry matter yield per pot (Figure 6), and may be due to shading by lower leaves in the plants when the dry matter yield was higher.

There were fewer leaves/tiller during the more prolonged interval of fertilizer application (Figure 2) and shorter blade length (Figure 5), which may have provided less shading and thus less leaf senescence. Treatments resulting in longer leaf blades may also have increased leaf senescence rates as $\mathrm{N}$ affects leaf expansion (Nabinger \& Pontes, 2001).

There was a cultivar effect on the number of tillers per plant (Table 2), although there were no effects of time of fertilizer application or cultivar and application times. As in experiment 1, the Marandu cv. values were higher compared with those of the Xaraés cv. (8.3 and 7.7 tillers per plant, respectively). In experiment 1 , the tiller number was higher in both cultivars (15.6 and 12.1, respectively), which may have been due to different $\mathrm{N}$ and $\mathrm{K}_{2} \mathrm{O}$ dosages. At the time of uniformity cutting, the mean number of tillers/pot was 5 in experiment 1 , and 3 in experiment 2 , which demonstrates the effect of $\mathrm{N}$ on tillering. The difference may be due to fertilizer doses before uniformity cutting ( 200 and $50 \mathrm{mg} / \mathrm{dm}^{3}$ of $\mathrm{N}$ and $\mathrm{K}_{2} \mathrm{O}$ in experiments 1 and 2, respectively) and the time or moment at which uniformity cutting was done (seven and two weeks after transplantation in experiments 1 and 2, respectively).

Nabinger (1997) stated that the tillering potential of a given genotype is determined by the time leaves arise; each fully grown leaf corresponds to a generation of one or more axillary buds. Dosages of $\mathrm{N}$ may also affect the number of tillers per plant. Silva et al. (2009) have estimated that the maximum number of tillers per plant in $B$. brizantha Marandu cv. was 12.8 , when fertilized with $179 \mathrm{mg} / \mathrm{dm}^{3}$ of $\mathrm{N}$. Alexandrino et al. (2004) found 34.1 tillers/plant after 45 days regrowth and application of $50 \mathrm{mg} / \mathrm{dm}^{3}$ of $\mathrm{N}$ each week in the same cultivar. The number of tillers in Brachiaria cultivars varies widely in the literature (Alexandrino et al., 2004; Martuscello et al., 2005; Silva et al., 2009), as this value is affected by combined nutritional, environmental, and management factors.

There was only a cultivar effect on plant height (Table 2); the Xaraés cv. was higher $(28.4 \mathrm{~cm})$ than Marandu cv. (21.6 cm), competing with Valle et al. (2001), who stated that the Xaraés cv. is larger than the Marandu cv. The recorded values were low, when taking into account that the plants were harvested at 39 days growth. Costa et al. (2007) reported heights ranging from 29.00 to $76.6 \mathrm{~cm}$ for $B$. brizantha cv. MG-5 when cut at intervals of 15 to 60 days.

There were no interactions of cultivar, time of fertilization, or effects of cultivar fertilization time on the accumulated blade length per plant; the mean value was $178.9 \mathrm{~cm}$. However, the accumulated blade length per tiller was affected by the time of fertilization (Figure 5). The lowest value for this variable was reached with fertilization at 12 days - the mean length was $17 \mathrm{~cm}$ in both cultivars. Thus, for each day of delay in applying fertilizers (relative to the cutting day), there was a $0.58-\mathrm{cm}$ reduction in the accumulated leaf length per tiller.

Premazzi et al. (2008) found a positive effect in leaf length in the Tifton 85 grass as dosages were increased ( 0 to $240 \mathrm{mg} / \mathrm{dm}^{3}$ ) and fertilizer ( $\mathrm{N}$ ) application times were changed (at zero and seven days). Alexandrino et al. (2005) found a quadratic effect for this variable; these authors attained a maximum length of $17.5 \mathrm{~cm} /$ leaf for the Marandu cv. fertilized with $90 \mathrm{mg} / \mathrm{dm}^{3}$. Martuscello et al. (2005) confirmed the influence of nitrogen fertilization on the leaf lengthening rate; the increase reached $37 \%$ for an $\mathrm{N}$ dose of $120 \mathrm{mg} / \mathrm{dm}^{3}$, compared with absence of nitrogen fertilization. Such an increase due to nitrogen fertilization may be attributed to a higher production of cells. The leaf lengthening zone is an active site with a high demand for nutrients; according to Skinner \& Nelson (1995) - cited by Nabinger \& Pontes (2001) - this is the reason why N directly affects the leaf expansion rate: it increases the cell number. Little $\mathrm{N}$ is deposited far from the leaf lengthening zone.

Only a cultivar effect was seen in the leaf blade/stem ratio (Table 2); the values were 2.4 (70.6\% blades) and 2.1 (67.5\% blades) for Xaraés and Marandu grasses, respectively. These values are much higher than those in experiment 1 , for both cultivars, and may be attributed to a delayed stem lengthening. The results are inverted in relation to experiment 1 , in which the Marandu cv. had higher leaf blade/stem ratio and proportion of leaf blades than the Xaraés cv.

The dry matter yield per pot was influenced by the cultivar (Table 2) and time of fertilization. Unlike experiment 1, the cultivar Xaraés had a higher yield - the mean value was $27.8 \mathrm{~g} /$ pot - while the cultivar Marandu

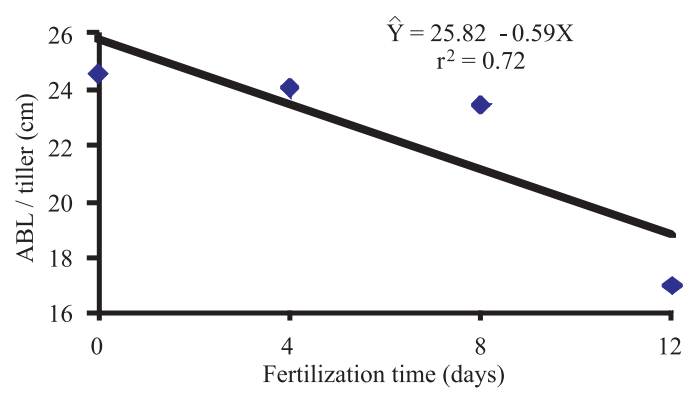

Figure 5 - Accumulated blade length (ABL) per tiller as a function of fertilization times after cutting (mean values of two Brachiaria brizantha cultivars). 
yielded $25.3 \mathrm{~g} /$ pot. The yields in experiment 2 were lower compared with those in experiment 1 . This result may have occurred due to differences in the quantities of $\mathrm{N}$ applied before the uniformity cutting, and at the time of uniformity cutting in relation to transplantation of plants in pots, which took place on five (experiment 1) and two weeks (experiment 2). It was reflected in the initial tiller number, which was higher in experiment 1 plants, and the growth period, which was 44 days (experiment 1 ) and 39 days (experiment 2). The effect of $\mathrm{N}$ on the dry matter yield has been widely reported in the literature (Martuscello et al., 2005; Rodrigues et al., 2006; Benett et al., 2008; Megda \& Monteiro, 2010). Monteiro et al. (1995) noticed that lack of this nutrient was the most significant limiting factor for the dry matter yield, tiller number, plant height, and nutrient concentration in the aerial portions and roots of the Marandu cv.

The time of fertilization was effective in increasing the dry matter yield (29.18 g/pot), which was attained when fertilization was done up to 4.5 days after cutting; yields decreased as fertilization intervals increased up to 12 days after cutting (Figure 6). The opposite was seen in experiment 1 , which may be explained by double doses of $\mathrm{N}$ and $\mathrm{K}_{2} \mathrm{O}$ applied in experiment $2\left(100 \mathrm{mg} / \mathrm{dm}^{3}\right)$.

There were no effects from any sources of variation in dry matter content, $\mathrm{N}$, crude protein (CP) or absorption of $\mathrm{N}$; the respective mean values were: dry matter $-22.44 \%$; $\mathrm{N}-1.9 \%$; CP $-11.7 \%$; and N/pot -0.42 g. Costa et al. (2007) found dry matter contents ranging from 16.0 to $26.6 \%$, and CP ranging from 16.02 to $8.86 \%$ in $B$. brizantha cv. MG-5 cut at 15- to 60-day cutting intervals, which showed the influence of plant age on these parameters. Monteiro et al. (1995) found a mean N content of $2.68 \%$ and absorption of $\mathrm{N}$ of $0.38 \mathrm{~g} /$ pot in the Marandu cv. that had been fertilized with all macronutrients. The CP content was within the range found by Benett et al. (2008) - 10.65 to $17.67 \%$ - in

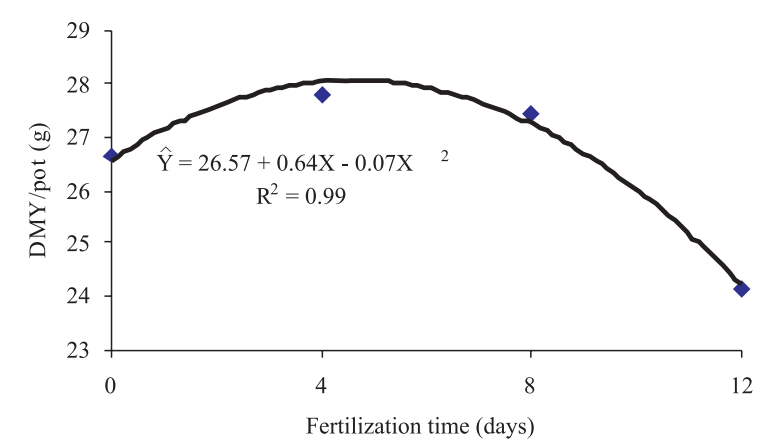

Figure 6 - Dry matter yield (DMY) per pot as a function of time of fertilization after cutting (mean values of the cultivars Xaraés and Marandu). an assessment of the effect of different dosages ( 0 to $200 \mathrm{~kg} / \mathrm{ha}$ cut) and sources of $\mathrm{N}$ on the characteristics of B. brizantha Marandu cv.

There was a cultivar effect on regrowth vigor (Table 2); there were, however, no fertilization time and cultivar fertilization time interaction effects. The highest value of regrowth vigor was seen in Xaraés cv. compared with Marandu (respectively 5.22 and 3.56 g/pot).

\section{Conclusions}

Applying $\mathrm{N}$ and $\mathrm{K}_{2} \mathrm{O}$ fertilizers immediately after cutting increases the total number of leaves and expanded leaves per tiller and the accumulated leaf blade length. Dry matter yield is maximized by applying fertilizers immediately after cutting by using lower doses of $\mathrm{N}$, or at 4.5 days after cutting by using higher doses of $\mathrm{N}$.

\section{References}

ALEXANDRINO, E.; NASCIMENTO JÚNIOR, D.; REGAZZI, A.J. et al. Características morfogênicas e estruturais da Brachiaria brizantha cv. Marandu submetida a diferentes doses de nitrogênio e freqüências de cortes. Acta Scientiarum, v.27, n.1, p.17-24, 2005.

ALEXANDRINO, E.; NASCIMENTO JÚNIOR, D.; MOSQUIM, P.R. et al. Características morfogênicas e estruturais na rebrotação da Brachiaria brizantha cv. Marandu submetida a três doses de nitrogênio. Revista Brasileira de Zootecnia, v.33, n.6, p.1372-1379, 2004.

BENETT, C.G.S.; BUZETTI, S.; SILVA, K.S. et al. Produtividade e composição bromatológica do capim-marandu a fontes e doses de nitrogênio. Ciência e Agrotecnologia, v.32, n.5, p.16291636, 2008.

CECATO, U.; MACHADO, A.O.; MARTINS, E.N. et al. Avaliação da produção e de algumas características da rebrota de cultivares e acessos de Panicum maximum Jacq. sob duas alturas de corte. Revista Brasileira de Zootecnia, v.29, n.3, p.660-668, 2000. COSTA, K.A.P.; OLIVEIRA, I.P.; FAQUIN, V. Intervalo de corte na produção de massa seca e composição químico-bromatológica da Brachiaria brizantha cv. MG-5. Ciência e Agrotecnologia, v.31, n.4, p.1197-1202, 2007.

EMPRESA BRASILEIRA DE PESQUISA AGROPECUÁRIA EMBRAPA. Centro Nacional de Pesquisa de Solos. Sistema brasileiro de classificação de solos. 2.ed. Rio de Janeiro, 2006. 306p.

FAGUNDES, J.L.; FONSECA, D.M.; MISTURA, C. et al. Características morfogênicas e estruturais do capim-braquiária em pastagem adubada com nitrogênio avaliadas nas quatro estações do ano. Revista Brasileira de Zootecnia, v.35, n.1, p.21-29, 2006.

GARCEZ NETO, A.F.; NASCIMENTO JÚNIOR, D.; REGAZZI, A.J. et al. Respostas morfogênicas e estruturais de Panicum maximum cv. Mombaça sob diferentes níveis de adubação nitrogenada e alturas de corte. Revista Brasileira de Zootecnia, v.31, n.5, p.1890-1900, 2002.

GOMIDE, C.A.M.; GOMIDE, J.A. Morfogênese de cultivares de Panicum maximum Jacq. Revista Brasileira de Zootecnia, v.29, n.2, p.341-348, 2000.

MARANHÃO, C.M.A.; SILVA, C.C.; BONOMO, P.; PIRES, A.J.V. Produção e composição químicobromatológica de duas cultivares de braquiária adubadas com nitrogênio e sua relação com o índice 
SPAD. Acta Scientiarum. Animal Sciences, v.31, n.2, p.117-122, 2009.

MARTUSCELLO, J.A.; FONSECA, D.M.; NASCIMENTO JÚNIOR, D. et al. Características morfogênicas e estruturais do capimXaraés submetido à adubação nitrogenada e desfolhação. Revista Brasileira de Zootecnia, v.34, n.5, p.1475-1482, 2005.

MEDEIROS, L.T.; PINTO, J.C.; CASTRO, E.M. et al. Nitrogênio e as características anatômicas, bromatológicas e agronômicas de cultivares de Brachiaria brizantha. Ciência e Agrotecnologia, v.35, n.3, p.598-605, 2011.

MEGDA, M.M.; MONTEIRO, F.A. Nitrogen and potassium supply and the morphogenic and productive characteristics of marandu palisadegrass. Revista Brasileira de Zootecnia, v.39, n.8, p.1666-1675, 2010.

MONTEIRO, F.A.; RAMOS, A.K.B.; CARVALHO, D.D. et al. Cultivo de Brachiaria brizantha Stapf. cv. Marandu em solução nutritiva com emissões de macronutrientes. Scientia Agrícola, n.52, n.1, p.135-141, 1995.

NABINGER, C. Eficiência de uso de pastagens: disponibilidade e perdas de forragem. In: SIMPÓSIO SOBRE MANEJO DA PASTAGEM, 14., 1997, Piracicaba. Anais... Piracicaba: Escola Superior de Agricultura “Luiz de Queiroz”, 1997. p.231-251.

NABINGER, C.; PONTES, L.S. Morfogênese de plantas forrageiras e estrutura do pasto. In: REUNIÃO ANUAL DA SOCIEDADE BRASILEIRA DE ZOOTECNIA, 38., 2001, Piracicaba. Anais... Piracicaba: Sociedade Brasileira de Zootecnia, 2001. p.755-771.

PEDREIRA, C.G.S.; MELLO, A.C.L.; OTANI, L. O processo de produção de forragem em pastagens. In: REUNIÃO ANUAL DA SOCIEDADE BRASILEIRA DE ZOOTECNIA, 38., 2001, Piracicaba. Anais... Piracicaba: Sociedade Brasileira de Zootecnia, 2001. p.772-807.

PREMAZZI, L.M.; MONTEIRO, F.A.; OLIVEIRA, R.F. Fornecimento de nitrogênio após o corte do capim-Bermuda Tifton-85: alongamento e comprimento de folhas. In: REUNIÃO BRASILEIRA DE FERTILIDADE DO SOLO E NUTRIÇÃO DE PLANTAS, 28., 2008, Londrina. Anais... Londrina: Embrapa Soja/IAPAR/UEL, 2008. (CD-ROM).

PREMAZZI, L.M.; MONTEIRO, F.A.; SCHIAVUZZO, P.F. et al. Doses de nitrogênio e momento de aplicação após o corte em características fisiológicas do Tifton 85. In: SIMPOSIO INTERNACIONAL GRASSLAND ECOPHYSIOLOGY AND ECOLOGY, 1999, Curitiba. Anais... Curitiba: UFPR, 1999. p.336-339.

PREMAZZI, L.M.; MONTEIRO, F.A. Produção do capim-tifton 85 submetido a doses e épocas de aplicação de nitrogênio após o corte. Boletim da Indústria Animal, v.59, n.1, p.1-16, 2002.

RIBEIRO, A.C.; GUIMARÃES, P.T.G.; ALVAREZ V., V.H. (Ed.) Recomendação para o uso de corretivos e fertilizantes em Minas Gerais: 5. Aproximação. Viçosa, MG: Comissão de Fertilidade do Solo do Estado de Minas Gerais, 1999. 359p.

RODRIGUES, R.C.; ALVES, A.S.; BRENNECKE, K. et al. Densidade populacional de perfilhos, produção de massa seca e área foliar do capim-xaraés cultivado sob doses de nitrogênio e potássio. Boletim da Indústria Animal, v.63, n.1, p.27-33, 2006.

SILVA, C.C.F.; BONOMO, P.; PIRES, A.J.V. Características morfogênicas e estruturais de duas espécies de braquiária adubadas com diferentes doses de nitrogênio. Revista Brasileira de Zootecnia, v.38, n.4, p.657-661, 2009.

SILVA, D.J.; QUEIROZ, A.C. Análise de alimentos: métodos químicos e biológicos. 3.ed. Viçosa, MG: UFV. 2002. 235p.

VALLE, C.B.; EUCLIDES, V.P.B.; MACEDO, M.C.M. et al. Selecting new Brachiaria for Brazilian pastures. In: INTERNATIONAL GRASSLAND CONGRESS, 19., 2001, São Pedro. Proceedings... Piracicaba: Fealq, 2001. (CD-ROM). 